\title{
The Art of Losing: Historical Allusions in Sherman Alexie's Reservation Blues
}

\begin{abstract}
In his capacity as poet, writer of novels and short stories and filmmaker, Sherman Alexie (b. 1966) has successfully bridged the cultural and social gap separating Native Americans from mainstream American society. With a combination of humor, wit, deep sensitivity, social satire and historical awareness, Alexie has effectively portrayed the contemporary plight of Native Americans isolated on reservations where many are doomed to live desperate lives on the distant periphery of American culture.

The present study is an attempt to enhance appreciation of Alexie's novel Reservation Blues (1996) by examining a network of historical allusions appearing in the novel that lay bare the military, economic and social forces that undermined Native American culture, especially that of the Plateau Indians in the American Northwest, including that of Alexie's own tribe, the Spokanes. The study draws upon ideas from recent historical studies such as Heather Cox Richardson's Wounded Knee (2010) and Elliot West's The Last Indian War (2009) as well as sources used by Alexie himself in the writing of the novel.
\end{abstract}

\section{Key words}

Historical allusions; civilization; crossings; periphery; Native Americans; reservation

Co je psáno, to je dáno. Czech proverb

The history of the North American Indians is one that until recently has been told primarily by the "victors" in the struggle for supremacy over the continent with the "losers" who lost not only their land and way of life but also their voice 
in expressing their version of events. The massacre at Wounded Knee was a triumph of politics in its aftermath in putting forth an official version of events that exonerated government officials from any culpability, praised the military and blamed tribes of the Sioux - the Minikonjou Lakota and Hunkpapa Lakota - for the tragic loss of 184 men, women and children; it effectively reduced the proud race to a captive people, subdued, crestfallen, sad, and all too few. ${ }^{1}$ Not only was the survivors' version of this event largely unheeded, but surviving Ghost Dancers who had been blamed for resisting government efforts to "Americanize" them and for instigating the incident were subsequently arrested. Within several months they were taken out of captivity by Buffalo Bill Cody who had them perform in his Wild West Show, including the Ghost Dance leaders Kicking Bear and Short Bull. For the show's many performances in America and abroad, the Sioux leaders were billed as prisoners of war from Wounded Knee and in deference to "civilized" society's preconceptions were forced to put their "savagery" on display. A defeated nation with no role to play in "civilized" society, Native Americans have long been marginalized on reservations located largely in peripheral regions of states across the American nation or have become a virtually invisible segment of mainstream society. Their version of events has largely been lost in the oral history of the Lakota and other native languages or in misinterpreted versions by unsympathetic or even hostile spokespersons (Richardson 2010: 294).

The writings of Sherman Alexie (b. 1966) serve to revive the Native American voice and make it heard in a most effective, prepossessing and broadly appealing manner. Attempts by non-natives to co-opt and exploit Native American values, images and spirituality rankle and enrage, yet Alexie manages to channel negative emotion into stories characterized by effective and mostly comic irony and incisive wit. His story War Dances (2009) begins with a section entitled "My Kafka Baggage": the reference to the personification of existential angst is explained by the questions posed by the narrator who having just returned from a flight opens his travel bag only to find a dead cockroach in it: "Who is lonelier than the cockroach without his tribe?" the narrator wonders. "I laughed at myself. I was feeling empathy for a dead cockroach. I wondered about its story. Crushed by shifts of fate and garment bags. Isolation? Existential dread?" (3).

The Alexie-like narrator also ponders on the notion of a given name: it should be a protective one given at birth. His own given name of Sherman recalls General William Tecumseh Sherman (1820-1891), the top-ranking Commander of the U. S. Army who oversaw the total defeat of the American Indian Nation in the post-Civil War era, and who himself bears the name of a Shawnee Chief - a strange reversed mirror image of Alexie himself. Sherman Alexie, in this story, accuses himself of being a racist, of stereotyping his own people, while at the same time, through his writing, he attempts to heal deep wounds. In a very powerful sense his writing as a whole can be seen as a response to Elizabeth Bishop's villanelle, "The Art of Losing" in which the poet states: "It's evident/The art of losing's not too hard to master/ though it may look like (Write it!) like disaster." (Arp 54) 
Alexie's writing addresses, among other things, his own sense of vulnerability and weakness in coming to grips with invasive forces conspiring to beat down the psyche and destroy any hope for well being - in particular the deep sense of guilt he feels for leaving the reservation. Sometimes, however, you have to lose yourself to save yourself and others. In his award-winning novel, The Absolutely True Diary of a Part-Time Indian (1996), the youthful narrator comments on having lost his grandmother and his father's best friend in quick succession. The adolescent Arnold Spirit is overwhelmed by grief which reduces him to a state of helpless despair and a permanent sense of loss; to give expression to his distressed state of being, he quotes from Euripides' Medea: "What greater grief than the loss of one's native land"? This in turn induces him to reflect on the notion of loss with respect to Native Americans: "We Indians have LOST EVERYTHING. We lost our native land, we lost our languages, we lost our songs and dances. We lost each other. We only know how to lose and be lost. Medea was so distraught by the world, and felt so betrayed, that she murdered her own kids. She thought the world was that joyless." (85). Coming to grips with the existential sense of loss and the all too concrete problems of survival in the modern world while retaining a sense of life's joy and wonder is at the heart of Alexie's writing.

Reservation Blues is Alexie's first novel, one in which he addresses the existential issue of life and death on the reservation and the necessity of leaving the reservation in order to survive. "Reservations were meant to be prisons, you know? Indians were supposed to move onto reservations and die. We were supposed to disappear. But somehow or another, Indians have forgotten that reservations were meant to be death camps." (RB 216-7). He wants to be Indian, but he also wants to be American, too; after all, America is the land of those who have left their birthplaces in search of a dream; the sense of belonging applies not only to home towns. Searching for and realizing the American dream is the birthright of all Americans and Alexie claims this right for himself and for the members of the Coyote Springs Indian Band, Thomas Builds-a-Fire, the band's founder and lead singer and song writer, Chess and Checkers Warm Water, members of the Coeur d'Alene Reservation and back-up singers, Victor Joseph, lead guitarist, and Junior Polatkin, drummer.

This study focuses on allusions made in the novel to two historical characters, George Wright (1803-1865) and Philip Sheridan (1831-1888), military men who as members of the U. S. Army recorded military defeats on the native tribes of the Northwest including Alexie's ancestors, the Spokanes, resulting in its members being forced to life on reservations. Much of the military action referred to in the novel and described in visions, dreams and nightmares took place in the late 1850s in the years just prior to the Civil War in the remote eastern Washington Territories, a time during which most Americans were focused on issues of slavery, states' rights, the coming divisive presidential election between Abraham Lincoln and Stephen Douglas, and secession.

The acknowledgements page of Reservation Blues Alexie lists a number of works on local Northwest history which Alexie made use of in writing the novel. 
He includes several sources by writers with a Spokane connection, one of whom came to Eastern Washington with his pioneer parents in the 1870s. Benjamin Franklin Manning (1824-1905) led a prominent public life in the Spokane area, and in 1912 he published The Conquest of the Coeur d'Alenes, Spokanes and Palouse, making generous use of military communiqués, reports, diaries and correspondence to provide a vivid account of the military expeditions of the U.S. Army in the Northwest and in particular the military defeat of Alexie's ancestors. Another source, also by a local Spokane native, is a biography entitled General George Wright: Guardian of the Pacific (1988) by Carl P. Schlicke. Reference is also made to Crazy Horse: The Strange Man of the Oglalas (1942) by Mari Sandoz. No specific acknowledgements are made to another major $19^{\text {th }}$ century military figure appearing in the novel, General Phillip Sheridan, a hero of the Civil War and the subject of numerous biographies. Two were consulted for this work. One, by Roy Morris, Jr. (1992), allots a separate chapter to Sheridan's experiences in the Pacific Northwest; a second, by Joseph Wheelan, Terrible Swift Sword (2012), gives short shrift to the 1850s and much more Sheridan's activities in the Civil War and the post-Civil War Indian Wars.

\section{II}

The story-telling art of Sherman Alexie comes alive in his novel Reservation Blues, welling up responses to pain and painful situations of Native Americans living on the Wellpinit Spokane Reservation in Eastern Washington and also the Flathead Reservation of Western Montana. Alexie has put Wellpinit on the map for most of his non-Indian readers. The reservation is a site of magical experiences featuring the mythical being of Big Mom and the resurrected blues musician Robert Johnson and his supernatural guitar. Thomas Builds-a-Fire, Alexie's inveterate story-teller and fictional alter ego, is a visionary who brings to life the past and present plight of the indigenous peoples in America. He is also a presence and a voice in other of Alexie's fictional works together with his alter-ego and fellow band member, Victor Joseph. ${ }^{2}$

Thomas is the novel's main protagonist, the lead singer and leader of the Coyote Springs Indian band. He is a vital literary creation whose wisdom and offbeat and often self-deprecating manner allow the non-Native American reader to transcend racial, social and historical barriers in developing a better understanding of the marginalized reservation existence of aboriginal Americans in general and the Spokane Indians of Eastern Washington state in particular. ${ }^{3}$ The novel provides insight on their long victimization by the forces of American Manifest Destiny, including their current over-dependence on a paternalistic bureaucratic government epitomized in the novel by the recurring acronyms HUD, BIA and IHS. ${ }^{4}$ At the same time, the resilience and imaginative resourcefulness of the characters allow them to come to grips with their troubled and tragic history in the Land of the Free. 
For educators Turk et al. (2007), the novel serves as a text that "provides a wealth of curricular material for history and social studies classrooms" (2007: 400). The novel as text provides social and historical contexts that in combination with other documentary sources "invite students to invest themselves not only in the facts but also in the stories of history" so as to "investigate the historical background of contemporary life in the United States. In regard to social studies, Alexie depicts in detail the "somewhat destitute lifestyle of 1990s reservation Indians" recounting the critical if widely known issues of poverty, alcoholism, substandard housing and unenlightened and unenlightening educational institutions (2007: 401).

A critical review by Gloria Bird, a Native Spokane insider, entitled "The Exaggeration of Despair in Sherman Alexie's Reservation Blues" (1995), questions the reliability of the text as a representation of the realia of reservation life and culture. It straightforwardly "questions the assumption that because someone is Indian what they produce is automatically an accurate representation" of what are construed to be "generic 'Indian' qualities" attributed to members of diverse tribes. The author claims that the novel depicts "an exaggerated version of reservation life, one that perpetuates many of the stereotypes of native people and presents problems for native and non-native readers alike" (1995: 46).

The author is also critical of the use of allusions to popular culture as lacking any overarching artistic purpose, serving only as the writer's means to keep the episodic plot moving forward. In the novel "[a]llusion is a device through which it becomes self-conscious of its own constructions." Writing as a native reader, Bird is concerned "with the colonialist influence on the native novel, and how that influence shapes the representation of native culture to a mainstream audience. It also cannot help but shape the native reader's relationship to the native novel." Bird sees Reservation Blues as a representative "native" novel, which, in actuality, "omits the core of the native community, and exists solely in the marginal realm of its characters who are all misfits: social and cultural anomalies. It is a partial portrait of a community wherein there is no evidence of Spokane culture or traditions, or anything uniquely Spokane" (1995: 48).

Bird's legitimate criticisms and reservations notwithstanding, the novel serves an important function by its capacity to cross borders - temporal, cultural and social - in an offhand, humorous way that invites the mainstream reader to consider life on the reservation and the broader issue of historical relations between colonialist "Americans" and autochthonous tribes. Its many allusions from the media and popular culture together with the unifying and universal power and allure of music create a familiarity, even an intimacy, which blurs the distinct boundaries between cultures. A closer examination of the historical allusions allows the reader to examine one of the darkest aspects of the American past - Manifest Destiny in its unrelenting continental expansion in the nineteenth century marked by its treacherous manipulation of the lives and wellbeing of Native Americans, its wholesale grabbing of their land, especially when gold was discovered, ${ }^{5}$ be it in Montana, Washington, Idaho, or the Black Hills of South Dakota, its failure 
to keep any of its treaties, and its wholesale destruction of the traditional Native American way of life. Yet Alexie maintains a sense of humor through it all, noting the Spokanes' ability to laugh with and at - "What did they have to laugh about? Poverty, suicide, alcoholism?" (RB 36). Laughing makes the priest feel closer to God, he affirms, and laughing at and with is welcoming to the reader.

Examining aspects of the historical subtext of the novel by extrapolating recurrent allusions to historical personages and events and explicating their historical significance serves to enrich the appreciation of the text and the Native American experience, especially that of Alexie's Spokane Tribe. ${ }^{6}$ In particular, echoes of the horrific act of General Wright's massacre of 700 horses are present in the novel as a recurring musical motif to provide historical reverberation to the existential experiences of Alexie's contemporary protagonists.

Historical allusions in the novel are numerous. Reference is made to Marcus and Narcissa Whitman, evangelical missionaries to the Northwest Indians in the 1840s who helped precipitate the great emigration along the Oregon Trail that gathered momentum in the 1840 s and became a critical threat to the traditional life of Native Americans in the following decade. In addition, several allusions are made to the massacre of the Lakota Sioux at Wounded Knee (1890) in South Dakota, considered as an iconic destructive act perpetrated by the $7^{\text {th }}$ U.S. Cavalry that was seen by some as a fitting retribution to the annihilation of Custer's $7^{\text {th }}$ Cavalry regiment at the Little Big Horn (1876) and marked an end to Native American hopes of maintaining an independent way of life, resisting assimilation of and conformance to the white man's civilization of material culture based on private property, a spiritual culture based on the tenets of Christianity and humiliating submission to an authoritarian and paternalistic government on reservations (Richardson 2010: 26).

\section{III}

Alexie can be seen, through his main protagonist Thomas-Builds-a Fire as repudiating violence as a means to achieve his ends, however noble or pragmatic, yet by the novel's end he is apparently at a loss at how to proceed to preserve his culture and tradition as well as his identity and Native American society. Much as his ancestors faced loss and near extinction against the overwhelming military force of the U.S. Cavalry and executive power on both the state and federal levels, Alexie's people face a similar threat to their existence both by the marketing forces of corporate America and reservation life itself. The former undermines Native American culture by co-opting it, distorting its image and stealing its soul; the latter by creating and maintaining conditions and institutions that have led to overdependence on the sovereign state for its well being, a dependence that has proven woefully inadequate, resulting in rampant poverty, alcoholism, unemployment, and inadequate educational and health facilities. Furthermore, as Alexie points out, individuals on the reservation largely fail to work together, 
and all too typically end up fighting each other. Like Alexie himself, Thomas reluctantly chooses to leave the reservation in the hopes of making a better life for himself and for Chess and Checkers, yet their future as "urban Indians" appears very uncertain. The reservation is diminishing and the urban jungle threatens with its anonymity: "And if you ain't got choices/What else do you choose?" (RB 1)

Yet the situation is not altogether hopeless. Whereas the negative relation of the unequal power structure can be seen in terms of exclusion, rejection, concealment, negation, denial, the insistence on rules and regulations and the determination of what is allowed and what is forbidden, Alexie provides an alternative power structure. The seeming uniformity of the power apparatus in American society reveals the same type of exercise at all levels of existence including that of sexuality and sexual desire; notwithstanding this state of affairs, the reader comes to behold a creative response to the monolithic structures of power. According to Foucault, power is something that is not acquired, seized, or shared, and there is no simple division of the powerful and powerless. Rather, power is immanently inside relationships, and not governed by them; instead, they have a productive role to play. The top-down model of power as evidenced in the novel's SheridanArmstrong relationship, an executive business model, is countered by the relationship in which power functions within a framework of choices and decisions made by individuals; where there is power, there is resistance. Though the novel posits power relations of a majority vis-à-vis minority, yet the latter retains its own elements and sources of power. This source of power is transformative and dynamic; one side learns from the other while maintaining their individual identity (2003: 59-60).

In the course of the novel, Thomas garners forces both internal and external. He gains power in offering resistance to the systemically empowered status quo, both on and off the reservation. Signs of resistance are evident in the songs that accompany each chapter, setting a tone and identifying themes that serve to create a new form of collective memory, and in so doing creates a spiritual force for resistance, identity and survival; the songs, together with the novel as a whole, enter into the historical record as a counter-historical rendition, undermining the mythic qualities of those holding sovereign power, while displaying inglorious acts and abuse of power. Alexie uses history as a means of undermining the authority of sovereign power, the history of power presented from the point of view of the wielders of power and the reinforcement of historical stereotyping. He creates a counter-history of resistance by undermining the heroic image of the U.S. Cavalry, imposing a restraint on social stereotyping and exposing the use and abuse of history over how things unfold and the use of violence to impose submission.

Alexie embraces resistance by empowering Thomas as song maker with the Native American mythical figure of Big Mom and the historical personage and legendary blues guitarist Robert Johnson (1911-1939), thereby endowing the novel with an imaginatively and musically rich texture that embraces North American Indian culture and history and extends to the world of Black music and musicians 
of the American Jim Crow South. Through Big Mom Thomas is invested with the vision, spirit and power of the horses slain by Colonel Wright's cavalry unit. The scream of the horses is a recurring motif that links the past with the present and accompanies Thomas, Chess and Checkers along their as yet unknown path in life. Robert Johnson's guitar gives expression to the slave experience, the pain of his ancestors and the longing for freedom. Big Mom and Robert Johnson are seen as both being capable of crossing cultural boundaries: Leaving the reservation and keeping the doors open to one's return is a major issue for Alexie and his characters. Robert Johnson, in finding a refuge with Big Mom on a mountain top overlooking the reservation, learns the Spokane ways. At the end of the novel he is seen wearing the traditional ribbon shirt and feeling a sense of belonging with Big Mom: "I think these Indians might need me. Maybe need my music." (RB 304)

Black-inspired blues allows Coyote Springs to give expression to the Native American condition. Johnson together with Big Mom appears throughout the novel in the form of salutary spirits embodying the creative and redemptive power of music. The merging of cultural values and expression is epitomized by Johnson's magical guitar which passes from Black hands to Spokane Indian hands. In the meantime Johnson seeks to regain his soul with Big Mom on the Spokane Indian Reservation. By bequeathing his indestructible guitar to Thomas Builds-a-Fire and through him to Victor, the band's lead guitarist, he breathes life into the soul of the Coyote Springs. For Thomas, the blues create memories of the Spokane past and present for a nation that fails to heed them: "Those blues lit up a new road, but the Spokanes pulled out their old maps. Those blues churned up generations of anger and pain: car wrecks, suicides, murders. Those blues were ancient, aboriginal, indigenous." (RB 174)

Thomas takes as a model for his inner strength and spiritual powers Crazy Horse, "the Strange Man of the Oglalas," who does whatever can be done to save his people. Both are filled with a restlessness to act, both burdened with the weight of the people upon their shoulders. Crazy Horse was a witness to a country already lost. He knew the truth, undermined by the depredations of the White Man, that "one does not sell the earth upon which the people walk" (Sandoz 1942: 252). The commissioners and agents out to profit from treaties have as their novelistic counterparts the recording agents and corporate agent Wright, Sheridan and Armstrong; one group demands the traditional lands of the Black Hills, the Powder River Country and the Big Horns; the other demands the image and culture, the very soul of the Native American to be marketed and sold. Crazy Horse informs us that Iron Man's brother killed his own father when crazy with the whisky of the whites. Thomas watches his father deteriorate from a warrior hero on the basketball court to a comatose alcoholic. Crazy Horse was a witness to all the bad deeds inflicted upon his people, fearful of the coming time. For him it was impossible to live in peace with the White Man who takes your heart and soul: "There is no country that can hold the tracks of the moccasin and the boots of the white man side by side." (303) Like Crazy Horse in the crisis period of the 1870s, Thomas feels the strength of the earth and sky around him; he is capable 
of reading nature through visions and dreams - just like "the Strange One" who wielded powerful "medicine" - healing and spiritual powers - and was a leader and fighter for his people. ${ }^{7}$ Thomas's magic is transmuted into stories and songs about the Native American condition.

The allusions made in the novel to Wounded Knee, ${ }^{8}$ marked by tragic and unnecessary loss of life, and the ultimate surrender of the Native Americans of their traditional way of life and their unwilling relegation to life on the reservation, are bound up with the novel's musical theme. The first Native American to fall in the melee at Wounded Creek was Black Coyote, who refused to give up his Winchester rifle. His fate together with his spirit and defiance give added historical resonance to the band's chosen name of Coyote Springs. In the novel, we read that "Big Mom's guitar was made of a 1965 Malibu and the blood of a child killed at Wounded Knee in 1890, the loneliest chord the band ever heard" (RB 206). In stating that it is "the chord all Indians can play" (RB 207) it is suggested that the range and depth of the band's music embraces the fate of all Native Americans, endowing it with an expansive healing power.

Thomas's gift of story-telling and singing the blues derives from his intuitive understanding and identification with the Native American historical condition. He looks into himself and he knows "his stories came from beyond his body and mind, beyond his tiny soul." His mystical powers share in the spiritual resources of his mystical forebears. He is present at Wounded Knee when the Ghost Dancers were slaughtered. "We were slaughtered at Wounded Knee," he declares. Historically, no Spokanes or Flatheads were present, but 'there was a part of every Indian bleeding in the snow. All those soldiers killed us in the name of God, enit? They shouted 'Jesus Christ' as they ran swords through our bellies. Can you feel the pain still, late at night, when you're trying to sleep, when you're praying to a God whose name was used to justify the slaughter?" (RB 167)

Thomas's voice combines joy and suffering. The Indian blues cuts through pain even as it gives voice to it. Thomas, the inveterate story-teller, is sensitive to the pain and anger buried deep in the bosoms of his fellow Spokanes who prior to the appearance of the band pay no heed to him or his stories. Nevertheless, Thomas's stories are recounted throughout the novel and the nature of his vision is reflected in the lyrics to the songs corresponding to the themes of the novel's chapters, including those of the reservation itself, faith, fatherhood and the urban Indian, the fate that awaits Thomas. The pent-up anger and anxiety induced by past collective experience and present life on the reservation are reflected in the attitudes of a defeated people: marked by a general apathy and lack of faith, the local denizens falling into the ruts of old routines, even by the way they listen to music without really listening. Thomas is forced to share his stories with trees "since his people don't listen to them, just didn't listen" (RB 28). They have heard too many promises in the past:

Treaties never remember/They give and take 'til they fall apart...Somebody breaks a hard promise/ Somebody breaks your tired heart - love ain't easy, it's just like signing a treaty (RB 31-32). 


\section{IV}

The blues is bound up with historical memory, especially the history of a people that has lost its freedom and whose collective spirit has been long oppressed. "The blues always make us remember" the guitar said (RB 22). Thomas's mother, dying of cancer, used to sing heartbreaking songs, glass-breaking sounds, traditional songs of the Spokane tribe to her little boy. Thomas, like a cedar flute, is privy to the tribe's songs, its blues, its longing for freedom; those blues fill Thomas with memories of the past. The guitar's message, its injunction to Thomas is the need for him to compose and perform songs for his people. Thomas hears music in everything: The penetrating power of music is like a rain shower over the landscape.

Recurrent references are made to the U.S. Cavalry, the nemesis of the Spokane and all other tribes of the Northwest and Great Plains in the second half of the nineteenth century. In the novel, the cavalry becomes associated with the powersthat-be and their apparent ability to enforce at will the maxim that "might makes right." The odds in dealing with representatives of authority and power are always stacked against Thomas and his band members, yet the very act of engagement is a form of resistance and a challenge to the system. Such is the case with Thomas's father, Samuel, a former high school basketball star. In his ten-on-two competition against members of the local police force, Samuel cannot beat the odds. He knows he will come up short but we see him dunking the basketball for his very life in an attempt to overcome the system - even for a moment as he soars through the air: "a ratify-a-treaty, abolish income-tax, close-the-uranium-mines dunk." He sees his slam dunk as a "strike against betrayal, of those part-blooded Indians who support the system that persecutes the Indians, the Indian scouts who helped the US Cavalry, for Wounded Knee I and II, for Sand Creek, for Martin Luther King and Malcolm X and for Jimi Hendrix" (RB 117). Once again, Alexie brings together Native and Black freedom fighters and a Black musician with Cherokee blood as allies in creating an alternative power structure.

Two cavalry leaders in particular are re-embodied in the present as agents, headhunters in a modern context, for a musical recording company. The blatantly named Cavalry Records is led by a certain Mr. Armstrong, a namesake of George Armstrong Custer (1839-1876) - the cavalry's most relentless Indian fighter bent on the genocidal extermination of the Native Americans. The driving purpose of the company is the for-profit exploitation of Thomas's Indian band. The agents from Cavalry Records, Phil Sheridan and George Wright, appear in their stereotypical nineteenth century hypostases: stocky, short, dark-haired, with moustaches taking over their faces.

The historical Philip Henry Sheridan (1831-1888) was a ruthless and aggressive commander who played a leading role in the U. S. Army's destructive campaigns against native peoples of the Northwest before the Civil War and those of the Great Plains in post-Civil-War America. He was one of the most highly regarded and highly decorated officers in the nineteenth century, and one of the 
most successful Union generals in the Civil War. He gained his early experience in the Pacific Northwest as a surveyor in the Willamette Valley and the Yakima and Rogue River Wars in the 1850s.

In 1857 Sheridan oversaw the transfer of Native Americans to a newly established reservation on the Siletz River in the newly organized Washington state and managed to avoid bloodshed by allowing them to keep some of their guns. This earned him a commendation for promoting peace between the Natives and soldiers. His sympathy was abetted by his intimate relation with the daughter of a Klikitat chief:

"Sheridan's untypical sympathy for the Indians, stemming from his companionship with Sidnayoh, the daughter of Chief Quately of the Klikitats of Williamette Valley, who shared his living quarters at Fort Hoskins and later at Fort Yamhill. Sheridan learned the Chinook language during his stay. For four years his main task was to deal with the hostile Rogue River Indians. His resourcefulness in subduing them and breaking their rebellious spirit, made them lose face with other Indians. Soon Sheridan had the entire reservation farming, attending church, and sending their children to the white man's school. Great strides had been made in civilizing these crude and superstitious people." (Morris 1992: 62)

Hardened by his Civil War experience Sheridan was appointed to head the Department of the Missouri to pacify the Plains Indians in ruthless fashion. He applauded the efforts to destroy the buffalo, lifeblood of the Plains Indians. By 1874 over four million had been killed off by hunters trespassing on Native American lands: "Let them kill, skin and sell until the buffalo is exterminated." He is associated with the statement that "the only good Indian is a dead Indian" (Morris 1992: 343-344).

Sheridan, unlike many others instrumental in the fate of the Native Americans, did not let politics interfere with his judgment and stayed free of the corrupting influence of power and money. He was praised by Winfield Scott for his energy, zeal and solid judgment in his eight years on the Indian frontier. He was ambitious, combative, and prickly and persistent in his attention to detail and to duty. With experience as a quartermaster under his belt, he understood the needs of the common soldier, excelled at managing, organizing and reorganizing men and supplies with a strong sense of accountability. He embodied the notion of complete conquest, the philosophy of Grant and Sherman after Shiloh (April 6-7, 1862, 24,000 casualties.) Whether Cheyenne or Confederate he maintained relentless pressure on the enemy that ensured victory. Through his military strategy of relentless warfare he succeeded in pacifying the tribes one after another, Kiowas, Cheyennes, Arapaho and bringing them to the reservation. His ongoing threat to hang all prisoners cowed the tribesmen into submission due to their concern for the dead and the sacredness of the body. Most Native American tribes believed that the souls of the dead passed into a spirit world and became part of the spiritual forces that influenced every aspect of their lives (Wheelan 2012: 373ff). 
The historical George Wright (1803-1865) played a more direct role with respect to the novel by his involvement with the Spokane Indians. He earned valuable experience under fire in the bloody and brutal Second Seminole War (1835-1842) and the Mexican-American War (1846-48) prior to his assignment in the 1850 s to the $4^{\text {th }}$ Infantry Regiment on the West Coast, including the Washington Territory. Wright's humane regard for the rights of Native Americans and his intention to save them from total extinction was expressed in his attempts to keep the races separate and out of harm's way, and secure their property rights by giving them land between the Cascade Mountains and the Columbia River. His was painfully aware of the fact that when the two races came into contact, Native Americans adopted white vices, and were either killed off by diseases transmitted by whites or by the whites themselves. Politicians, such as Isaac Stevens (18181862), the first governor of Washington State, saw the Indians in completely negative terms as depriving white settlers of their God-given land (Schlicke 1988: 127). The politicians were abetted by local newspapers in rousing anti-Indian sentiment: "What are the lives of a hundred or a thousand of these savages to the life of a single American citizen... We say shoot them down wherever you find them..." (Shasta Courier March 1853 in Schlicke 1988: 101).

Wright fought in the Yakima War (1855-1858) and the critical Battle of Four Lakes near present-day Spokane. Yet, the event that binds him indelibly to Spokane history was his successful attempt to subdue the local tribes by his order to slaughter their horses. On September 8, 1858, over 800 Native American horses were destroyed at Liberty Lake to prevent their use by local tribes. This was the culminating act in a punitive military expedition against the Yakama, Spokane, Palouse, and Coeur d'Alene tribes, which had defeated Lieutenant Colonel Edward Steptoe's force on May 17 and 18, 1858. Horses represented both wealth and their effectiveness in making the Northwest Natives an elusive enemy. This loss left them devastated (Stimson 1985: 16).

In Stimson's account, on that fateful September 8 on the way to the Coeur d'Alene Mission a large herd of horses the army had come upon was captured by Lt. Davidson and Lt. Mullan - 800-900 horses thought to belong to Tilcoax, a troublemaker of the Palouse. The herd was driven to the campsite sixteen miles above the falls. The Native American "owner" was hanged under order of Wright. Horses were the most prized possessions of the local tribes. Attempts to recapture them could result in a stampede which would threaten the army's horses. A council of officers determined to kill most of the horses to prevent them from falling back into the hands of their owners. At first individual horses were shot execution style; then they were fired upon in volleys into a makeshift corral, a task requiring two days, conferring the name Horse Slaughter Camp to the site. Members of the tribes witnessing the event were flabbergasted at the wholesale destruction of such valuable and prized animals, which had "a devastating effect on their morale." The tribal leaders were now ready to sue for peace. Wright then proceeded to Lake Coeur d'Alene, site of Fort Sherman, destroying Native cattle and food supplies found in lodges along the way. "The chastisement which these Indians 
have received has been severe but well merited, and undoubtedly necessary to impress them with our power. For the last eighty miles our route has been marked by slaughter and destruction" (Stimson 1985: 178). Polatkin, for whom Junior Polatkin of the Coyote Springs band is named, served as chief of the Spokane tribe and symbolized renewed good will between whites and the Coeur d'Alenes in his opposition to shedding the blood of whites.

Shooting the horses took the better part of two days. Initially, 150 of the horses were to be used for Wright's own troops, but they proved restive and so were destroyed as well. The carcasses rotted into piles of bones that marked the site that became known as Horse Slaughter Camp near what later became Aturdee, east of Spokane (Stimson 1985: 16).

The execution of the horses is a pivotal moment in Spokane history, a moment which Alexie appropriates as a subtext for his novel. The screams of the horses at the time of the massacre serve as the novel's dominant motif, signifying the tribe's loss of freedom, and serving as the underlying source of the reservation blues.

The first indirect reference to George Wright in the novel appears in the vision of Big Mom who incorporates the scream of the horses into a melodic motif or refrain recurring throughout the novel. The scream of the horses becomes the pained and tortured song of the tribe; it is the song of the coming of white settlers and white soldiers. Big Mom, the embodiment of historical memory and Native American blues, makes the "horse song" part of her vision of creative renewal; the song long silenced, is heard anew in all its violence and pain with the coming of Robert Johnson:

"Big Mom heard the first gunshot... all she heard were the gunshots, singular at first, and then in rapid plural bursts that she could not count she goes to the clearing where the horses gathered: There she saw the future and the past, the white soldiers in blue uniforms with black rifles and pistols, watching the horses fall until only one remained. Big Mom watched the Indian colt circled by soldiers. The officer, [Wright] stepped down from his pony, walked over to the colt, gently touched its face, and whispered in its ear. The colt shivered as the officer put his pistol between its eyes and pulled the trigger." (RB 10)

An extended and detailed dream sequence in the novel first introduces Sheridan and Wright ${ }^{9}$ as historical figures in their army uniforms. Junior Polatkin has a dream in a motel lobby in Seattle on the eve of the Battle of the Bands, but his dream takes him back to an earlier battle: He dreams about horses, and sees himself riding his own horse along the Columbia River, leading a group of warriors in a frustrated 
attack on a steamship; he hears in the distance the sound of bugles, then gunshots. All of his men are cut down save for Junior. He hears a deafening voice "Drop your rifle" and was dragged from his horse by unseen hands. He is thrown to the ground, kicked and beaten." In his dream the soldiers are at first invisible; then he sees white men in blue uniforms, laughing and spitting on him. One soldier places a pistol between his pony's eyes and pulls the trigger. "The horse took a long time to fall. He learns that the large soldier who had killed his pony and now helps him to his feet is "General George Wright." The general defends his action by declaring bluntly and matter-of-factly: "This is war." (RB 143)

Junior is overpowered, bound and dragged, as he awaits the appearance of "General Sheridan, an even larger white man who reads from a document: "You've been charged with the murder of eighteen settlers this past year. How do you plead?" Not guilty. "Well, well, Sheridan said. I find you guilty and sentence you to hang by the neck until you are dead." Junior is dragged to the gallows. "Junior closed his eyes in his dream. He heard a sportscaster in the distance. 'Ladies and gentlemen, we're here to witness the execution of Spokane Indian warrior Junior Polatkin for murder. Eighteen murders, to be exact. Quite a total for such a young man. General Sheridan and General Wright are presiding over the hanging."”

"I can save your life" Sheridan said. "Sign this." Junior is untied and given a pen but throws it away. "The pen revolved and revolved. The sun rose and set; snow fell and melted. Salmon leapt twenty feet above the surface of the Columbia River, just feet from the hanging."

When asked to pray, he prays in his own way by singing. "In his dream, Junior started his death song and was barely past the first verse when the platform dropped from under him and the rope snapped tightly." (RB 144)

Junior's dream of his death by hanging foreshadows the taking of his own life by blowing his brains out, an act prompted by his growing sense of his spiritual emptiness and his failure to make anything of his life. In particular he falls into a trough of despair in reflecting upon his painful love affair with a white co-ed and his realization that he is powerless to transcend the gulf of prejudice he encounters in life outside the reservation. His suicide leaves the band fragmented, shatters the spirit of Victor and darkens the creative endeavor of the novel. Yet his actions in the dream reveal a different side of him. His refusal to sign an agreement with Sheridan, his casting away of the pen, and his singing of a death song are all acts of resistance that give impetus and inspiration to Alexie and his alter-ego Thomas. The revolving motion of the pen signifies a change of direction in the power relations of the antagonists, a loosening of the grip of the cavalry officers and its ultimate destination in the creative hand of Thomas.

Sheridan's historical role here is mirrored by his contemporary one as agent for Cavalry Records in his attempt to get Coyote Springs to sign the dotted line of a recording contract. Sheridan is intent on exploiting the band's appeal and the growing market for an Native American band solely for the company's material benefit. Sheridan and Wright make their way to the reservation to talk about 
a recording contract with Coyote Springs, the newest incarnation of tribal music, a music that scares and excites whatever white people are in attendance. It's the kind of music that "might have chased away the pilgrims five hundred years ago." (RB 80) Sheridan and Wright instinctively sense this power and ship off the band to New York City to capitalize on the band's appeal.

Victor, who acts as Thomas's alter-ego, is the heart and soul of the band. Yet he is a complex and disturbed individual, proud and angry, with warrior blood flowing in his veins. He is aggressive, prone to violence, his short fuse ever ready to explode. The chip on his shoulder stems in large part from the sexual abuse he suffered at the hands of a missionary priest when he was nine. Yet "Victor wanted to win." (RB 230) Thomas makes him the band's lead guitarist, Robert Johnson's blues guitar instinctively placing itself in Victor's hands. When the band begins its recording session, however, Victor's guitar senses an exit

Victor's warrior blood, however, refuses to give him peace. He seeks revenge against the white establishment by chasing white women, which for him was like stealing horses; it was "the best kind of revenge against white men." (RB 233) Victor is forced to show his vulnerable side after Junior, his best friend and the person he loves the most, shoots himself. He feels most responsible for this terrible, senseless loss and this shakes him to the core. Furthermore, he has lost the guitar, left behind in the New York studio and soon begins to lose himself. This is made painfully clear by his realization that Junior will no longer be around to take care of him. His feeble attempt to seek employment with the Reservation's Tribal chairman goes awry as the latter tosses his resumé into the wastebasket. This barely legible resumé lays bare the painful realities of the reservation's "edgeucation" system (RB 297), calling to mind Huckleberry Finn's words of wisdom that apply to Victor and so many Native Americans: "a body that don't get started right when he's little, ain't got no show - when the pinch comes there ain't nothing to back him up and keep him to his work, and so he gets beat." (HF 113) Victor reverts to his alcoholic ways, boding ill for his future well being, his vitality and powers of resistance sadly diminished.

After the fiasco with Coyote Springs, Sheridan cajoles Betty and Veronica, Indian wannabees and lovers of Junior and Victor, into signing a contract. In so doing the girls behave as their counterparts did in the 1870 s, the half-breed sons of traders who served as guides to the cavalry in tracking down Native Americans still offering resistance. In manipulating and marketing the spirit, experience and music of Native Americans and thereby transforming them into a money-making enterprise, Sheridan deforms their image and identity. Sheridan declares to the girls: "But there's a whole lot of marketing we have to do" such as "fine tuning your image." For Sheridan, Betty and Veronica are "Indian enough." He offers them a promise of fame and fortune: "You do things for us, we can do things for you" It's a partnership in the dream business, making dreams come true in return for a little sacrifice." (RB 272)

The actual recording of Betty and Veronica's "Indian" music produced by Cavalry Records is perceived by Thomas as an act of treachery, an invasive encroachment 
of the Native American collective soul. Listening to the lines: "And my hair is blonde/ But I'm Indian in my bones/ And my skin is white/ But I'm Indian in my bones" enrages him and puts him on the warpath; yet all he can do is to destroy this particular tape, knowing all too well the song will soon hit the airwaves and become a hit. It is one more defeat in the Native American struggle for integrity, and, coupled with Junior's death, leaves him and the remaining band members increasingly vulnerable and disoriented.

Though Sheridan is partially responsible for the downfall and demise of the Indian rock band Coyote Springs, he takes on a much more invasive and insidious role by his haunting appearances in Checkers' dreams. Checkers' confrontation with Sheridan begins in the studio when she throws the money proffered by Sheridan as a form of consolation back into his face. In the first of such dreams, Sheridan appears in his dual role as soldier and music agent, expressing his deeply upsetting frustration at the shortcomings of the band and the Native Americans as a whole, caused by their reluctance to take any blame for their defeats both in the musical world and on the battlefield. He wields his cigarette like a saber, preaching to Checkers as if reproving the entire Spokane Nation: 'We gave you every chance. All you had to do was move to the reservation. We would've protected you. The U.S. Army was the best friend the Indians ever had."' Sheridan shows his true colors of a proud and victorious military commander who wants his due reward while directing his animosity toward and frustration with the recalcitrant "losers": "Always fighting, never listening to orders, never staying put. We won the war. We keep winning the war. But you won't surrender. We still kept trying to change you. Tried to make you white. It never worked." (RB 237)

Sheridan continues to be fascinated by the beauty of the Native American female in the person of Checkers, studying and admiring her features. "He had watched her during the last few centuries. She was beautiful...She had arms strong as any man's... and black, black hair that hung down past her shoulders." Sheridan's dream is, however, Checkers' nightmare, yet she refuses to be intimidated, squaring off with Sheridan instead: "I don't believe in you. You're just another white guy telling lies. I don't believe in you. All you want to do is fight and fuck. You never tell a story that's true. I don't believe in you." (RB 241) Checkers' recurring nightmare is a microcosm of the relentlessly tragic fate visited upon the Native American world: tragedy after tragedy largely unknown to the outside world. The nightly visitations of Sheridan, threatening her, drawing her blood, render her seemingly helpless to remove his presence in her life be it as businessman or cavalry officer. Yet her unwillingness to acknowledge neither him nor his domineering presence and her bold declaration of lack of faith in him and his world view is another act of resistance that gives her the strength to save herself.

One other and most unlikely source of support comes in the person of the Spokane's nemesis, General Wright. As opposed to Sheridan, Wright expresses misgivings both at the handling of Coyote Springs and in the historical treatment of the Native Americans. In New York, Wright washes his hands of the business deal with Betty and Veronica. He appears to want to do the right thing, though as 
a military commander, he had to follow orders and those orders were to subdue the warring tribes using the most effective means at hand. Yet he retains his integrity by treating the Native Americans even-handedly and by his ability to see them as human beings: "they want the same things we do" (RB 229). As a kind of reward, he is transported back home to his final resting place, a cemetery in Sacramento (d. 1865). Yet his conscience refuses to give him peace, as he is still haunted by the sounds of horses screaming. He displays his poignant awareness of the everlasting debt he owes his fellow human beings: "Wright looked at Coyote Springs. He saw their Indian faces. He saw the faces of millions of Indians, beaten, scarred by smallpox and frostbite, split open by bayonets and bullets. He looked at his own white hands and saw the blood stains there." (RB 244) Alexie rewards Wright's contrite change of heart by providing for a sense of closure for the general that is a magnanimous act of forgiveness. He records the words etched on Wright's monument that serves as gravestone for himself and his wife: "Lovely and pleasant in their lives,/and in their death they/ were not divided." He allows Wright to transcend the historical irony with a posthumous confession of his crime of mass-extermination: "His wife patted his head as he wept and remembered all those horses who had screamed in that field so long ago. He remembered shooting that last colt while Big Mom watched from the rise... 'I was the one who killed them all. I gave the orders." This act of recognition of the genocidal acts imposed on the Native American people by the American nation is a step toward healing and mutual understanding. His final words in the novel, "I'm a killer. I'm a killer," are powerfully resonant (271).

Alexie allows Wright to come home and in so doing offers a refuge to all others seeking to come to terms with an inglorious past. In his rewriting of American history, Alexie conjures up the ghosts of the past, places them in a contemporary context that allows for some degree of atonement and hopes for closure from the historical nightmare. In giving expression to the roar of the slaughtered horses, he allays restive fears, if not entirely dispelling them. Yet the idea of coming home for Thomas and the band members is rendered doubtful and open-ended. They are seen as unwelcome traitors by the people of the reservation and set off to an uncertain future in the contemporary metropolis where they are bound to take up the identity of the urban Indian, invisible and unrecognized and alien. Yet in recognizing this profound sense of loss, Alexie, by taking pen in hand, has created a powerful network of creative and spiritual forces to resist and hopefully overcome further encroachment on the well being and livelihood of Native Americans.

\section{Notes}

Only in 2005 did the historian Richard E. Jensen record the in-depth carefully constructed oral history of Eli S. Ricker dating from 1903 published as Ricker Indian Interviews. See also Utley (1983) and Hoxie (2001). 
2 "Because My Father Always Said He Was the Only Indian Who Saw Jimi Hendrix Play "The Star-Spangled Banner' at Woodstock (1993) and "Crazy Horse Dreams" 1998.

3 The Spokane Tribe of Indians, known as the Children of the Sun, are of the Interior Salish Group, which has inhabited northeast Washington, northern Idaho and western Montana for many centuries. The Spokane Tribe, numbering about 2,600 members - little more than a small American town - now lives on 159,000 acres in Wellpinit, Washington, part of the larger and predominantly white community of Spokane, Washington.(Wynecoop 1969: 1-2)

$4 \quad$ Housing and Urban Development (HUD), the Bureau of Indian Affairs (BIA) and Indian Health Service (HIS), respectively.

5 "Whites follow the smell of gold as hungry Indians follow the buffalo" (Sandoz 1942: 284).

$6 \quad$ The Spokanes suffered from devastating diseases introduced by white settlers, diseases such as small pox and measles for which they had no natural defense. In addition, land-grabbing by white settlers was exacerbated by the lack of legal controls in the Wild West as yet to be incorporated as territories and thousands of miles away from the nation's capital. After the Civil War in the 1860s, settlers arrived in the Oregon Territory in overwhelming numbers, pushing out the original inhabitants, such as the Spokanes. The Spokane Indians, among many other Native American tribes, were given English names. The Spokanes made a number of agreements with the federal governments in the late 19th century. In 1877 the Lower Spokane relocated to the Spokane Reservation which was declared a reservation in 1881. In 1887 the Upper and Middle Spokane agreed to move to the Colville Flathead Reservation. (Wynecoop 1969: 5-7).

7 Crazy Horse is associated with song as well, as in the quiet, soothing voice of the Mother singing to her child: Sleep, my little owl, no soldiers come shooting./ This is a good place./ The medicine of the Strange Man (i.e. Crazy Horse)/ Covers all the people./ Sleep, my little owl-“"(346)

8 The Christmas Holiday in a field of freshly fallen snow the sight of bodies scattered on the ground, the wailing and mourning, the singing of death songs, eighty bodies found in what was to have been the council area for negotiating a peaceful surrender, mostly women and girls frozen stiff and cold, mothers and their daughters with seven survivors found among the dead with a new tally of 184 dead among the Indians in the council region, the whites taking souvenirs, including a Ghost Dance shirt from victims, 146 of whom were dumped into a mass grave, including that of the leader and negotiator not allowed to negotiate for his people, Big Foot. The fate of Big Foot's Minneconjous instilled the conviction among Indians that dealing with the Whites would be suicide, singing death songs, dancing the Ghost Dance (Richardson 2010: 257).

$9 \quad$ The scene from the novel foreshadowing Junior Polatkin's suicide draws upon an actual face-to-face meeting of the two soldiers which took place on March 27, 1856 when then Lt. Sheridan arrives from Fort Vancouver on the steamboat Belle with a detachment of forty dragoons; a planned attack by Sheridan on Yakimas, Cascades and Klickitats is dispersed by Wright's approach. Cascades Indians are captured and nine are hanged under jurisdiction of Wright. Hangings deemed justifiable for the killing of 19 whites in a so-called unprovoked attack, known as Cascades Massacre, at the sight of a portage in the Columbia River Valley.

\section{References}

Alexie, Sherman (1996) Reservation Blues. New York: Grove Press.

Alexie, Sherman (2005) The Lone Ranger and Tonto Fistfight in Heaven. Grove Press: New York. Alexie, Sherman (2007) The Absolutely True Diary of a Part-Time Indian. Google Books.

Alexie, Sherman (2013) Blasphemy. New York: Grove Press.

Arp, Thomas R. and Greg Johnson (eds.) (2008) Sound and Sense, $12^{\text {th }}$ edition. Boston: Thomson-Wadsworth. 
Bird, Gloria (1995) “The Exaggeration of Despair in Sherman Alexie's 'Reservation Blues"”. Wicazo Sa Review 11 (2): 37-52.

Falzon, Christopher et al. (ed.) (2013) A Companion to Foucault. Oxford: Wiley-Blackwell.

Foucault, Michel (2003) "Society Must Be Defended." Lectures at the Collège de France 19761976 (Trans. David Macey). New York: Picador.

Hoxie, Frederick E. (2001) Talking Back to Civilization: Indian Voices From the Progressive Era. Boston: Bedford.

Jensen, Richard E. (ed.) (2005) The Indian Interviews of Eli S. Ricker, 1903-1919. Lincoln: University of Nebraska Press.

Morris, Roy, Jr. (1992) Sheridan: The Life and Wars of General Phil Sheridan. New York: Crown Publishing.

Richardson, Heather Cox (2010) Wounded Knee: Party Politics and the Road to an American Massacre. New York: Basic Books.

Sandoz, Mari (1942) Crazy Horse: The Strange Man of the Oglalas. Lincoln, NE: University of Nebraska Press.

Schlicke, Carl P. (1988) General George Wright: Guardian of the Pacific Coast. University of Oklahoma Press.

Stimson, William (1985) A View of the Falls: An Illustrated History of Spokane. Northridge, CA: Windson Publications.

Stone, Brad Elliot (2013) “Power, Politics, Racism.” In: Falzon, Christopher et al. (ed.) A Companion to Foucault. Oxford: Wiley-Blackwell, 353-367.

Turk, Diana et al. (2007) "Mingling Fact with Fiction: Strategies for Integrating Literature into History and Social Studies Classrooms." The History Teacher 40 (3): 398-407.

Twain, Mark (1999) The Adventures of Huckleberry Finn. Edited by Thomas Cooley. New York: W.W. Norton \& Company.

Utley, Robert M. (1983) The Indian Frontier of the American West, 1846-1890. Albuquerque: University of New Mexico Press.

West, Eliot (2009) The Last Indian War: The Nez Perce Story. Oxford: Oxford University Press.

Wheelan, Joseph (2012) Terrible Swift Sword: The Life of General Philip H. Sheridan. New York: Da Capo Press.

Wynecoop, David C. (1969) Children of the Sun: a History of the Spokane Indians Wellpinit. Washington: David C. Wynecoop.

Joel J. JANICKI was born in Milwaukee, Wisconsin (USA). He studied at the Institute of Polonia Research, an affiliate of the Jagellonian University in Krakow, Poland, and earned his Ph.D. from the University of Illinois - Champaign-Urbana. He is currently Professor in the English Department of Soochow University in Taipei, Taiwan, where he teaches courses in American Literature, Polish Language and Culture and the Contemporary Novel. Recent publications include studies devoted to Andrei Bely's Petersburg, Pushkin's The Captain's Daughter, American themes in the poetry of Czeslaw Milosz and Issues in Taiwanese Identity.

Address: Dr. Joel J. Janicki, English Department, Soochow University, 70, Linhsi Rd., Shihlin, Taipei 11102, Taiwan. [email: joeljanicki@yahoo.com] 
